\title{
A VATICANUS REGINENSIS GRAECUS 103 ÉS A CHALKOKONDYLÉS-SZÖVEGHAGYOMÁNY*
}

A ma Vaticanus Reginensis Graecus 103 jelzetet viselő görög kézirat első név szerint ismert tulajdonosa a párizsi könyvgyűjtő, Paul Pétau / Paulus Petavius (1568-1614) volt. A kódex $1^{\mathrm{r}}$ és $174^{\mathrm{r}}$ foliumainak alján megtaláljuk a Pétau-család sphragisként szolgáló mottóját is, a Synesios 50 . leveléből - némileg pontatlan formában - átvett mondatot:

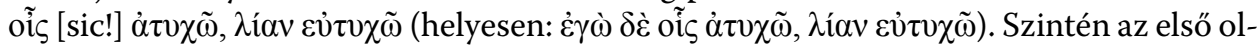
dalon, közvetlenül a jelmondat fölött a tulajdonos neve is szerepel, mégpedig PPetauius alakban. ${ }^{1}$ A széles látókörrel és nagy olvasottsággal rendelkező családfő halála után fia, Alexandre Pétau / Alexander Petavius (1610-1672) örökölte meg a könyvtárat, benne a szóban forgó kéziratot is. Az ifjabbik Pétau apjával ellentétben többre tartotta a könyveknél az egyéb természetű anyagi javakat, úgyhogy aztán 1650-ben Isaac Voss / Isaak Vossius (1618-1689) leideni gyűjtő és könyvtáros közvetítésével túl is adott öröksége jelentős részén, mintegy 1500 kódexen. ${ }^{2}$ Így jutott az akkor még a családi nyilvántartás szerint 1320-as sorszámot viselő kézirat ${ }^{3}$ Stockholmba, Krisztina svéd királynő (1626-1689) tulajdonába, aki a katolizálását követő lemondása után magával vitte Rómába, utóbb pedig az ő hagyatékából került végül kacskaringós utat bejárva mai őrzési helyére, az Apostoli Szentszék könyvtárának Bibliotheca Reginensis gyüjteményébe. ${ }^{4}$

A Reginensis 103 valamikor a XV-XVI. században keletkezett, 174 foliumból álló, vegyes tartalmú, quaternio papírkódex. Figyelemre méltó, hogy amikor Bernard de Montfaucon (1655-1741) 1680 és 1689 között összeállított monumentális katalógusában tételesen leírta Krisztina örökségét, a kézirat tartalmaként még kizárólag Diogenés Laertios művét jelölte meg. ${ }^{5}$ Ennek oka valószínűleg egyszerủ tévedés volt, de elvben nem zárhatjuk ki azt a lehetőséget sem, hogy a kódex ekkor még csakugyan ezt az egy müvet tartalmazta (teljes vagy már akkor is töredékes formában). A 174r Pétausphragisa ugyanis mindössze annyit bizonyít, hogy a kézirat utolsó íve (R: $156^{\mathrm{r}}-174^{\mathrm{v}}$ ) is biztosan olyan kódex része volt, mely a család könyvtárához tartozott, de amint azt látni

\footnotetext{
* A tanulmány a NKFIH K 134301 és az NKFIH NN 124539 jelzetű pályázatok támogatásával készült. A kéziratot digitális fényképek segítségével tanulmányoztam.

${ }^{1}$ Vö. K. A. De Meyier: Paul en Alexandre Petau en de geschiedenis van hun handschriften, voornamelijk op grond van de Petau-handschriften in de Universiteitsbibliotheek te Leiden. Leiden (1947) 24-25.

${ }^{2}$ De Meyier: $i$. m. (1. j.) 128-131.

3 De Meyier: i. m. (1. j.) 199: „Nummer van Alex. Petau 1320”.

${ }^{4}$ A Bibliotheca Reginensis keletkezéséről, történetéről és állományáról részletesen lásd B. Dudík: Iter Romanum. Im Auftrage des hohen Maehrischen Landesausschusses in den Jahren 1852 und 1853 unternommen und veröffentlicht. I. Theil: Historische Forschungen. Wien (1855) 123-180.

${ }^{5}$ B. de Montfaucon: Bibliotheca bibliothecarum manuscriptorum nova I. Paris (1739) 34, nr. 931: „Diogenes Laërtius de vitis Philosophorum”. Vö. Les manuscrits de la Reine du Suède au Vatican. Réédition du catalogue de Montfaucon et cotes actuelles. Città del Vaticano (1964) 53: „931 = Reg. gr. 103”.
} 
fogjuk, mindebből nem feltétlenül következik, hogy az R betűvel jelölt ívfüzet eredetileg is a Reginensis 103 részét képezte. Ráadásul a Pétau-család katalógusa a tartalom megjelölésekor szintén kizárólag a Diogenés Laertios-műről tesz említést, s ennek megfelelően a kéziratot a filozófiai tárgyúak közé sorolja be. ${ }^{6}$

Az első modern - több pontatlanságot is tartalmazó - katalógus leírásának összeállítója a kézirat nagyobb részében olvasható Diogenés Laertios filozófus-életrajzok szövegrészletei mellett $\left(1^{\mathrm{r}}-90^{\mathrm{v}}\right)$ már Laonikos Chalkokondylés történeti művének minket közelebbről érdeklő terjedelmes szemelvényeit is felismerte $\left(91^{\mathrm{r}}-154^{\mathrm{v}}\right),{ }^{7}$ később pedig a kézirat két további fragmentumának pontos azonosítása is megtörtént. Az üres $156^{\text {rv }}$ után következő $157^{\mathrm{r}}-172^{\mathrm{v}}$ egy Mazaris-töredéket őrzött meg, míg a kódex utolsó oldalain $\left(173^{\mathrm{r}}-174^{\mathrm{r}}\right)$ egy Polybios-fragmentum (VI, 15-17) található. $^{8}$

Ami immár a kézirat Chalkokondylés-részét illeti, az Apodeixis szövegét tartalmazó ívek több, általában összefüggő, rövidebb-hosszabb részletet őriztek meg a műből, de a szövegrészletek sorrendje a kódex egyes ívfüzeteinek keveredéséből adódóan zavaros. A Chalkokondylés müvét legutóbb kiadó Darkó Jenő közlése szerint az összekeveredett quaterniók tartalmának sorrendjét Lorenzo Alessandro Zaccagni (1652-1712), néhai szentszéki könyvtáros próbálta helyreállítani, ${ }^{9}$ mégpedig úgy, hogy lapszéli megjegyzésekkel azonosította az egyes könyveket. ${ }^{10}$ Érdemes itt in extenso idéznünk Darkó leírását: „A quaterniók sorrendje a bekötés alkalmával összezavarodott, a mit először Alex. Laur. Zaccagni (†1713 [sic!]) vett észre, a vatikáni könyvtár egykori igazgatója, s széljegyzeteiben helyre is állította az eredeti sorrendet a következőképpen: fo. 139-146 (ezt a quaternio-füzetet ő P-vel jelölte), fo. 147-154 (Q; Q és P közt egy quaternio kiesett), ez után hiányzik egy quaternio, fo. 123-130 (N), fo. 99-106 (K), fo. 91-98 (I), fo. 131-138 (O), ez után hiányzik két quaternio, fo. 107-114 (L), folytatólag kiesett több quaternio, fo. 115-122 (M), L és M más kézzel vannak írva, mint a megelőzők." ${ }^{11}$

A szűkszavú áttekintés értelmezése első olvasásra nem könnyű. Bár Darkó a Chalkokondylés-helyek sorrendje szerint veszi számba a foliumokat, nem határozza meg, hogy pontosan honnan, a történeti mű melyik részéből származik az adott ív szövege. A megfogalmazásból továbbá egyenesen következik, hogy Darkó szerint a kézirat vala-

${ }^{6}$ Vö. De Meyier: i. m. (1. j.) 48: „Vatic. Reg. Gr. 103: Diogenes Laertius' levens enz. van philosophen bevattend”, majd 50: „Vat. Reg. Gr. 103: inhoud philosophisch”.

7 H. Stevenson: Codices manuscripti Graeci Reginae Svecorum et Pii PP II. Bibliothecae Vaticanae. Roma (1888) 74-75.

8 Előbbihez lásd H. Wurm: Ein neuer Textzeuge des Mazaris? JÖB 40 (1990) 359-363; A. Cataldi Palau:

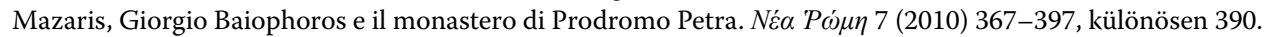

9 Zaccagni működéséről lásd C. Elissoneo [S. Salvini]: Lorenzo Alessandro Zaccagni. In: Notizie istoriche degli Arcadi morti II. Roma (1720) 49-54.

${ }_{10}$ Ugyanezt a módszert alkalmazza a Diogenés Laertios-szöveg esetében. Hogy pontosan mikor foglalkozott Zaccagni a kézirattal, nem tudjuk. Mivel fő pártfogója, az Ágoston-rendi Enrico Noris bíboros 1700-tól 1704-ig működött főkönyvtárosként, valószínűleg Zaccagninak is hozzávetőleg ebben az időszakban volt lehetősége foglalkozni a Chalkokondylés-szöveggel.

11 Vö. Darkó J.: Laonikos Chalkondylés újabb kéziratairól. EPhK 37 (1913) 645-666. Az idézett részlet a 652. oldalon olvasható. 
mikor az Apodeixis teljes szövegét tartalmazta, csak éppen bizonyos ívek rossz helyre kerültek, míg más ívfüzetek elvesztek. Ez a vélelmezés annak ellenére sem bizonyítható, hogy néhány ív között egyértelmü a kapcsolat, és a meglévő részletek közötti hiányok pedig csakugyan lehetnek quaternio terjedelműek. Az ívfüzetek jelölésére szolgáló, az egyes quaterniók kezdő foliumának rectóján a jobb alsó sarokba írt nagybetűknek tulajdonképpen semmi közük a töredékek eredeti sorrendjéhez, hiszen a betűk a jelenlegi kötésnek megfelelően mechanikusan, ABC-rendben követik egymást, vagyis szempontunkból rossz sorrendben jelölik a quaterniókat. Sajnos semmit nem tudunk a kézirat Darkó által említett (újra?)kötéséről, ${ }^{12}$ ami vélelmezése szerint a hiányzó ívek kiesését (?) és a meglévő ívek sorrendjének összekeveredését okozta. Ennyi és ilyen mértékű hiba azonban az első kötés alkalmával, mikor a könyvkötő fokozottan törekszik arra, hogy gondosan járjon el az ívfüzetek sorba rendezésekor és minden szempontból kifogástalan munkát végezzen, szerintünk aligha történhetett. Sokkal inkább elképzelhetőnek tűnik, hogy a jelenlegi helyzet nem az első és eredeti, hanem egy későbbi kötés során alakult ki, de nem találtunk adatot arra vonatkozóan, hogy mikor, miért és ki köttette újra a kódexet, már ha erre csakugyan sor került. A kéziratok kötésének cseréjét általában fizikai sérülések indokolják, esetleg egy-egy adásvétel szolgáltathat rá alkalmat, amennyiben az új tulajdonos az ízlésének jobban megfelelő, könyvtárához jobban illeszkedő kötésben szeretné kézbe venni szerzeményét. Ha a kézirat többször is gazdát cserél, ahogy azt a Reginensis 103 esetében láttuk, és a tulajdonosváltásokkal járó megpróbáltatások (csomagolás, szállítás) halmozottan jelentkeznek, a kódexet is nagyobb eséllyel éri fizikai sérülés. Az újrakötés folyamata során a kézirat tartalma már csakugyan könnyebben változhat, hiszen ilyenkor újból részeire kell szedni, majd később összeilleszteni az íveket, s ebben még akkor is viszonylag nagy hibalehetőség van, ha valamennyi ívfüzet sértetlenül megmaradt, nem is beszélve arról, ha néhány még el is veszett közülük. A kézirat tartalmi változása azonban többféleképpen is elképzelhető: az eredeti anyag terjedelme nemcsak csökkenhet egy sérülés miatt (ahogy ebben az esetben Darkó gondolta), hanem éppen ellenkezőleg, új ívek kéziratba kerülése sem zárható ki, de akár mindkettő együtt is bekövetkezhet. Ad absurdum akár úgy is történhetett volna, hogy a Reginensis 103 eredeti tartalmából, Diogenés Laertios filozófiatörténeti müvéből valamilyen úton-módon (például a szállítás során keletkezett fizikai sérülés miatt) elveszett néhány ív, később aztán valaki (az eladó?, az új tulajdonos?) észrevette a hiányt, s hogy pótolja a terjedelmi veszteséget, jobb híján más kézirat(ok)ból származó ívekkel, jelen esetben leginkább Chalkokondylés-quaterniókkal kiegészítve köttette újra a kódexet. Bár fenti elképzelés talán csábítónak tűnhet - annál is inkább, mert megfelelő magyarázattal szolgálna mind a Montfaucon-katalógus tartalmi leírásának tévedésére, mind az alább említésre kerülő datálási anomáliákra -, mindez bizonyíthatatlan, nem több puszta találgatásnál, márpedig semmiképpen nem lehet célunk igazolhatatlan elméletek erőltetése.

Kétségtelenül leszögezhetjük azonban, hogy nem tisztázható megnyugtatóan az a rendkívül fontos kérdés, miszerint a jelenlegi Reginensis 103 egyes ívei (1) eredetileg is

12 A kézirat kötéséről nem készültek digitális felvételek. 
kivétel nélkül ehhez a kézirathoz tartoztak-e, és csak annak fizikai sérülése, szétesése, ebből adódóan néhány ív elvesztése, majd a megmaradtak pontatlan újrakötése során kerültek egymás mellé, ${ }^{13}$ más szóval a kódex eredetileg is tartalmazta-e Chalkokondylés művét, vagy (2) a kézirat különböző részei (köztük az Apodeixis-szöveget tartalmazó ívek vagy azok egy része) már eleve legalább kettő, esetleg több másik kódexhez tartoztak, és valamilyen okból kifolyólag csak később kerültek egymás mellé (rossz sorrendben) a Reginensis 103-ban.

Szorosan idetartozik a datálás kérdése is. A kézirat keletkezési idejének pontos megállapításában azonban komoly nehézséget jelent, hogy míg a papíron felismert vízjel alapján a Reginensis 103 a XV. század közepén készülhetett, ${ }^{14}$ addig a teljes kódex kilenc kezéből eddig egyedüliként azonosított írnok, az L és M betűkkel jelölt ívek összefüggő Chalkokondylés-részletét másoló Antónios Eparchos (1491-1571) leghamarabb is mintegy hat évtizeddel később, a XVI. század első felében másolhatta a neki tulajdonított szöveget, ${ }^{15}$ arról nem is beszélve, hogy Chalkokondylés műve az 1463. év eseményeinek ismertetésével ér véget, márpedig ha a kézirat csakugyan tartalmazta az Apodeixist, bajosan készülhetett el hamarabb, mint maga a mű. ${ }^{16} \mathrm{Az}$ ellentmondás feloldható, ha feltételezzük, hogy a vízjel csak a Diogenés Laertios-részleteket fenntartó íveken látható, vagyis csak ez az egység keletkezett a XV. század derekán, míg a Chalkokondylésívek más kézirat(ok)ból kerültek a Reginensis 103-ba, és az Apodeixis-quaterniók (L és M mindenképpen) már a XVI. század első felében készültek. Mindez azonban csak valamennyi ív vízjelének megállapításával, vagyis a kézirat alapos vizsgálatával dönthető el (ha ugyan eldönthető egyáltalán), ez pedig pillanatnyilag nem áll módunkban.

A Chalkokondylés-szöveget tartalmazó íveken magunk az alábbi tizenhét bejegyzést tekintjük Zaccagni kezétől származónak: ${ }^{17}$ (1) $91^{\mathrm{r}}$ az oldal tetején: ex Historia Laonici Chalcocondylae Libri aliquot ut plurimum imper- / fecti. Incipit a Tertio, qui

${ }^{13}$ NB. Már a kézirat első felében olvasható Diogenés Laertios-ívek sorrendje is pontatlan. Vö. Stevenson: i. m. (7. j.) 74-75; E. Martini: Analecta Laertiana. Leipzig 1899. 101-102; T. Dorandi: Laertiana. Capitoli sulla tradizione manoscritta e sulla storia del testo delle Vite dei filosofi di Diogene Larzio. Berlin - New York (2009) 7.

14 Vö. Dorandi: i. m. (13. j.) 7: „Filigrane: ‘bilancia’ ( Briquet 2445: a. 1441).” A leírásból nem derül ki, hogy Dorandi pontosan mely íve(ek)n / folium(ok)on látta a „mérleget”. Vö. C. M. Briquet: Les filigranes. Dictionnaire historiques des marques du papier I. Paris (1907) 183: „Balance dans une cercle, à plateaux rectangulaires. 2445. 30x44 r, Vicence, 1441 A. not.: Minute di Giacomo Ferretto. Var. ident.: Venise, 1442; Innsbruck? 1443-45; Tolede, 1446; Nuremberg, 1448."

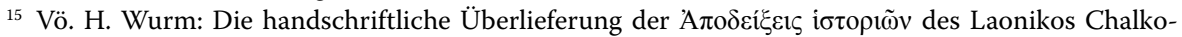
kondyles. JÖB 45 (1995) 230-231: „die Lagen L und M offenbar von der Hand des jungen Antonios Eparchos stammen, wie ein Vergleich mit der von Eparchos 1506 im Alter von 15 Jahren fertiggestellten Londoner Evangelienhandschrift zeigt.” A teljes kézirattal kapcsolatban lásd Dorandi: i. m. (13. j.) 7: „Copiato da nove mani diverse. Una è quella di Antonio Eparco (ff. 107r-122v)".

16 Talán ez indokolta Martini: $i$. m. (13. j.) 101 óvatosabb datálását („conscriptus est saec. XVI”). Ezzel szemben Dorandi: i. m. (13. j.) 7: „XV/XVI s.”

17 A sortörést dőlt vonal jelöltük. Néhány esetben Zaccagni törölni próbált egyes szavakat, s a többszöri, vastag áthúzás miatt a fényképen ilyenkor szinte olvashatatlan a szöveg. Az emiatt bizonytalan olvasatokat szögletes zárójelek közé tettük. 
caret initio. Pag. 139;18 (2) 98v az oldal alján: continuatur pag. 131; (3) 106v az oldal alján:

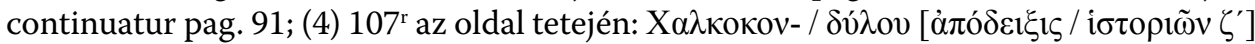

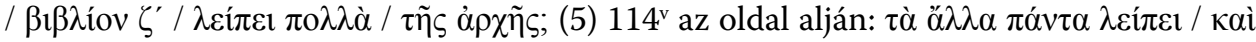

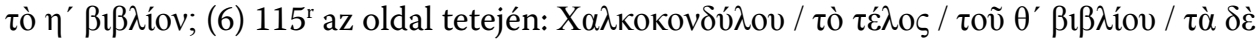

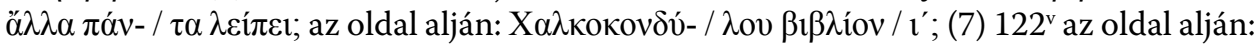

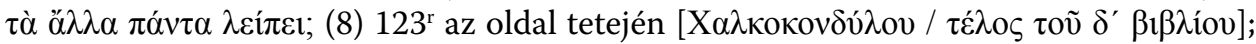

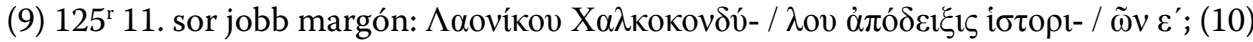

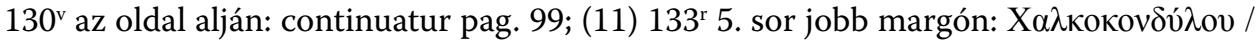

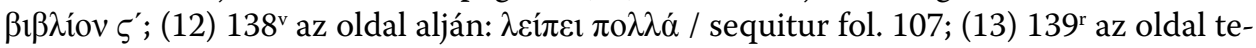

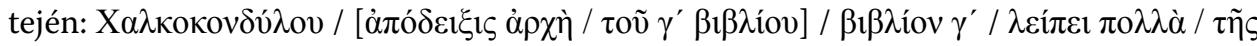

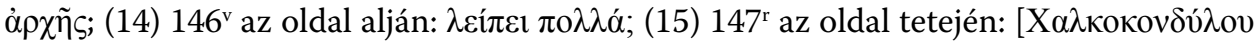

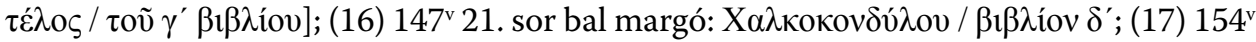

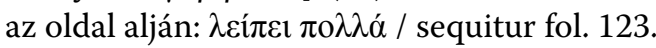

A tartalom pontos azonosítását szolgáló Zaccagni-„,széljegyzetek” mellett a szóban forgó foliumokon - ellentétben Darkó megállapításával ${ }^{19}$ - néhány marginális bejegyzés, többnyire a figyelem felkeltését szolgáló $\sigma \eta \mu \varepsilon i ́ \omega \sigma \alpha ı$ utasítás rövidítése, illetve egy-két kisebb javítás is található. Ezek a következők: $92^{\mathrm{r}} 18$. sor jobb margón megis-

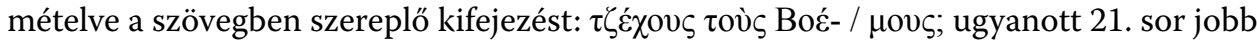

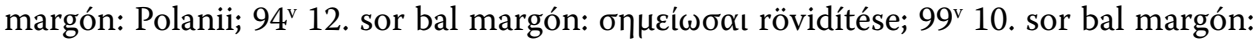

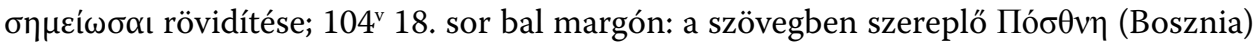
földrajzi névhez Пó $\sigma v \alpha ; 112^{\mathrm{r}} 12$. sor bal margón: $\sigma \eta \mu \varepsilon i ́ \omega \sigma \alpha$ rövidítése; $116^{\mathrm{v}} 12$. sor bal margón: $\sigma \eta \mu \varepsilon i ́ \omega \sigma \alpha \iota$ rövidítése; $119^{\mathrm{r}} 20$. sor bal margón: $\tau \rho \alpha \pi \varepsilon \zeta o v ̃ v \tau o \zeta$ három ponttal jelzett betoldás a szövegbe (Eparchos javítása); 119 7. sor bal margón: $\sigma \eta \mu \varepsilon^{\vee} \omega \sigma \alpha 1$ rövi-

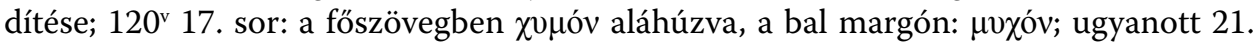
sor bal margón: $\sigma \eta \mu \varepsilon i ́ \omega \sigma \alpha$ r rövidítése; $121^{\mathrm{r}} 14$. sor bal margón: $\sigma \eta \mu \varepsilon i ́ \omega \sigma \alpha$ l rövidítése; ugyanott 20. sor: a főszövegben $\chi v \mu \tilde{\omega}$ aláhúzva, a jobb margón: $\mu v \chi \tilde{\varphi} ; 122^{v} 22$. sor bal margón: a föszöveg $\alpha \dot{\alpha} \alpha \pi i ́ \delta \omega v$ szavában a $\xi$ három ponttal javítva, helyette a bal margón:

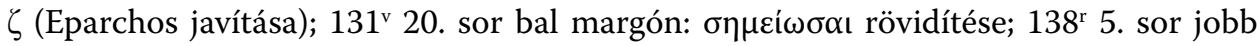
margón: megismétlődik a főszöveg nehezen olvasható Гє $\lambda \varphi \tilde{\omega} v$ szava (a másoló keze).

A Reginensis 103 (a Chalkokondylés-stemmában hagyományos jelzete N) összességében tehát a foliumok / quaterniók sorrendjében az alábbi Apodeixis-részleteket tartalmazza: ${ }^{20}$

$$
\begin{aligned}
& 91^{\mathrm{r}}-98^{\mathrm{v}}(\mathrm{I}): \mathrm{V}, 47-\mathrm{V}, 74 ; \\
& 99^{\mathrm{r}}-106^{\mathrm{v}}(\mathrm{K}): \mathrm{V}, 18-\mathrm{V}, 47 ;^{21} \\
& 107^{\mathrm{r}}-114^{\mathrm{v}}(\mathrm{L}): \text { VII, } 28-\text { VII, } 52 ;
\end{aligned}
$$

${ }^{18}$ Az oldalszámmal Zaccagni a kézirat foliumait jelöli.

19 Vö. Darkó: i. m. (11. j.) 652: „sem czímek, sem széljegyzetek nincsenek”.

${ }^{20}$ A folium megjelölését előbb zárójelben az adott ívfüzet Zaccagni-féle betűjele, végül az Apodeixis könyv- és fejezetszáma követi. A fejezetek számozásában Kaldellis kétnyelvü, görög-angol kiadását követem: A. Kaldellis: Laonikos Chalkokondyles. The Histories I-II. Dumbarton Oaks (2014).

${ }^{21}$ A K-ív margóira Zaccagni semmit nem írt, de az N-ív végén (130va alján) jelzi: continuatur pag. 99. 


$$
\begin{aligned}
& 115^{\mathrm{r}}-122^{\mathrm{v}}(\mathrm{M}): \text { IX, } 108-\mathrm{X}, 22 ; \\
& 123^{\mathrm{r}}-130^{\mathrm{v}}(\mathrm{N}): \text { IV, } 55-\mathrm{V}, 18 ; \\
& 131^{\mathrm{r}}-138^{\mathrm{v}}(\mathrm{O}): \mathrm{V}, 74-\mathrm{VI}, 23 ; \\
& 139^{\mathrm{r}}-146^{\mathrm{v}}(\mathrm{P}): \text { III, } 23-\mathrm{III}, 48 ; \\
& 147^{\mathrm{r}}-154^{\mathrm{v}}(\mathrm{Q}): \text { III, } 71-\mathrm{IV}, 21 .
\end{aligned}
$$

Vitán felül áll, hogy a Chalkokondylés-szöveg néhány íve szorosan összetartozik. Magunk az első ívcsoportnak az L- és M-íveket tekintjük, melyeket, ahogyan arról korábban esett szó, már pusztán a másoló személye is összeköt, de biztos, hogy a második ívcsoport tagjai, vagyis az I, K, N és O betűkkel jelölt ívfüzetek is eredetileg egy és ugyanazon kézirat részeit képezték, csak más sorrendben $(\mathrm{N}, \mathrm{K}, \mathrm{I}, \mathrm{O})$. Ahol ugyanis az N-ív szövege

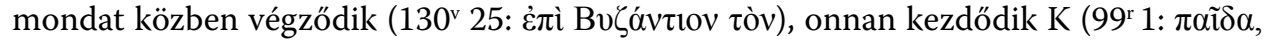

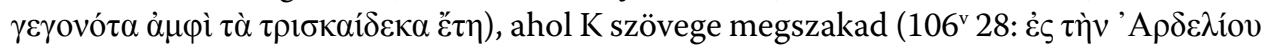
$\chi \omega ́ \rho \alpha v)$, pontosan onnan folytatódik I (91 ${ }^{\mathrm{r}} 1$ :

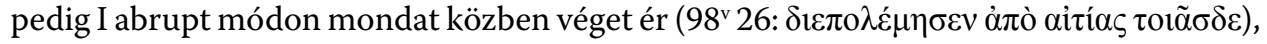

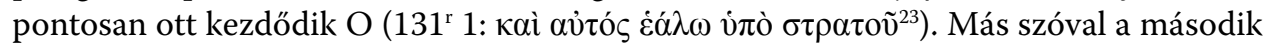
ívcsoport egy kódexhez tartozó fenti négy íve IV, 55-től egészen VI, 23-ig folyamatosan, hiánytalanul hozza az Apodeixis szövegét. Ebben a szakaszban az új könyvek kezdetét mindössze az jelzi, hogy a másolók új sort kezdenek: a IV. könyv az N-ív 125 11 . sorának elején ér véget, az V. könyv pedig a következő sorban kezdődik, míg az V. könyv szövege az O-ív 133 5 . sorának közepén ér véget, majd a sor második fele itt is üresen marad, a következő sorban pedig minden különösebb jelzés nélkül már kezdődik a VI. könyv. Nem ilyen egyértelmű a kapcsolat a harmadik ívcsoport, vagyis P- és Q-ív esetében, mivel a szöveg itt nem folyamatos, ugyanis a két ívfüzet között egy nagyobb, amint Darkó helyesen jelzi, kb. quaternio terjedelmű szövegmennyiség hiányzik, ennek ellenére a két ív írásképe közötti hasonlóság alapján a quaterniókat összetartozónak tekintjük. Nem pusztán az egyes betűk vagy betűkapcsolatok formájára gondolunk, hanem a helyesírási sajátosságok, az íráskép egészének a jellege, a végeredménynek az azonos típusú hibákból fakadó egyenletesen megbízhatatlan színvonala és általában a két ívfüzet vizuális hasonlósága is a kéz azonosságára utal. ${ }^{24}$ Amennyire a felvételek alapján megállapítható, ugyanez a kéz, a harmadik ívcsoport keze másolta a második ívcsoport foliumainak túlnyomó többségét is. Mindez a színvonalban is megmutatkozik: mindkét csoport szövegében viszonylag sok a hiba, kisebb-nagyobb tévesztés, következetlenség, kihagyás. A Q-ívben előforduló könyvváltás némileg különbözik a második ívcsoport két említett helyétől: az Apodeixis III. könyve a $147^{\vee} 21$. sorában ér véget, a IV. könyv pedig egy sor kihagyásával (bár egyéb jelzés nélkül) kezdődik. Feltehetően az üresen hagyott helyre került volna más színű tintával a cím, s alighanem ugyanígy szerette volna később pó-

22 A szövegkiadásban $\tau \varepsilon$ helyett $\delta \varepsilon$ áll.

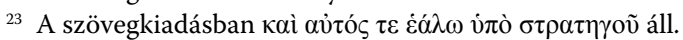

${ }^{24}$ Az összehasonlítás szempontjaihoz és problémáihoz vö. P. Canart: Identification et différenciation de mains à l'époque de la renaissance. In: La paléographie grecque et byzantine. Paris (1977) 363-369. 
tolni a másoló a könyvet elkezdő szó elhagyott kezdőbetűjét ( $\mu \varepsilon t \alpha ́$ praepositio helyett csak عtó látható a szövegben). Összességében azonban, ha szigorúan fogalmazunk, a három ívcsoport közötti szorosabb kapcsolatot sem kizárni, sem egyértelműen bizonyítani nem tudjuk. A második és harmadik ívcsoport közti szoros kapcsolat ugyan valószínű, de az első ívcsoportot minden tekintetben különbözőnek látjuk.

A fentebb ismertetett bizonytalanságokból is következik, hogy a Reginensis 103 helye a Chalkokondylés-hagyomány stemmájában jelen tudásunk szerint nem egyértelmü. Herbert Wurm megállapítása szerint a kódex Apodeixis-íveinek másolói az egyik müncheni Chalkokondylés-kéziratból, a Monacensis Graecus 307a-ból ( $\left.\mathrm{M}_{1}\right)$ dolgoztak, kivéve az L- és M-quaterniókat jegyző Antónios Eparchost, aki a másolás során a fóa meghatározó kéziratát, a Parisinus Graecus 1781 (Z) jelzetű kódexet tekintette mintának. ${ }^{25} \mathrm{Az}$ állítás utóbbi részéhez semmi kétség nem fér, sőt ezen a ponton még újabbakkal is kiegészíthetjük Wurm érveit. Egyértelmű bizonyítéknak tekintjük ugyanis, hogy nemcsak az oldaltörések esnek pontosan egybe mindvégig, ${ }^{26}$ hanem további egyezések is megfigyelhetőek, mégpedig éppen annak köszönhetően, hogy az ifjú Eparchos megpróbálja tökéletesen utánozni a másolati példányt: átveszi valamennyi $\sigma \eta \mu \varepsilon i ́ \omega \sigma \alpha ı$ jelet, ${ }^{27}$ ugyanúgy a szó fölé írt vonallal jelöli a tulajdonneveket, ugyanazzal a díszítőmotívummal választja el egymástól a könyveket, a másolati példányban színes tintával írt címet, iniciálét és díszítést kihagyja, hogy később akár más, akár személyesen maga színessel pótolhassa (ez végül elmaradt), ${ }^{28}$ az eredetiből hiányzó részt pedig ő is gondosan üresen hagyja. ${ }^{29}$ Sőt, buzgósága egy alkalommal olyan különös szövegváltozatot eredményez, amit érdemes közelebbről is szemrevételeznünk. A Parisinus 1781 222 foliumá-

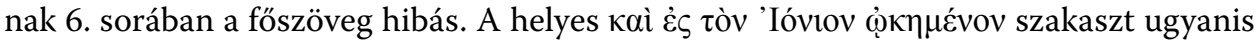

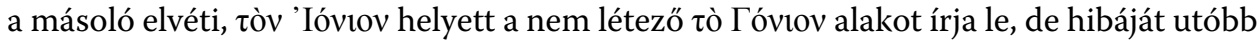
észreveszi, három ponttal jelzi és a bal margón javítja a helyes olvasatra. A három pontot azonban Eparchos félreérti, a betoldás jelének tekinti, a szövegben pedig ennek megfelelően meghagyja a téves formát, de mellé beemeli a helyes változatot is, így lesz nála

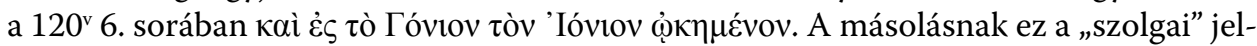

${ }^{25}$ Vö. Wurm: i. m. (15. j.) 231: „Während der übrige Teil des Reginensis eine sehr schlampige Abschrift mehrerer namentlich nicht bekannten Kopisten aus dem Monacensis 307a ist, dürften die beiden von Eparchos mit wesentlich größerer Sorgfalt kopierten Lagen nach dem mit dem Monacensis aufs engste verwandten Parisinus 1781 von der Hand des Georgios Moschos - bekanntlich einem Verwandten des Eparchos - angefertigt worden sein, mit dem sie auch durchgehend im Seitenumbruch exakt übereinstimmen."

${ }^{26}$ A Reginensis 103 „Eparchos-foliumai” $\left(107^{\mathrm{r}}-122^{\mathrm{v}}\right)$ az oldaltörés tekintetében a Parisinus 1781 $145^{\mathrm{r}}-152^{\mathrm{v}}$ és $217^{\mathrm{r}}-224^{\mathrm{v}}$ foliumainak felelnek meg.

27 Ezek: $112^{\mathrm{r}}, 116^{\mathrm{v}}, 119^{\mathrm{v}}, 120^{\mathrm{v}}, 121^{\mathrm{r}}$.

28 A Parisinus $1781217^{\mathrm{r}}$ foliumán ér véget a IX. és kezdődik a X. könyv. Utóbbit a színes tintával írt

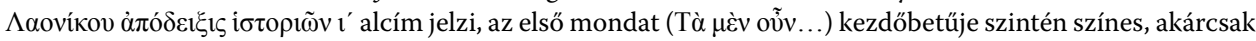
a két könyvet elválasztó díszítés bizonyos részei. Minden, ami színes, a Reginensis $103115^{\mathrm{r}}$ foliumán üresen marad, miközben a díszítés nem színes elemei ugyanúgy, ugyanabban a formában jelennek meg.

${ }^{29}$ A Reginensis $103110^{\mathrm{r}}$ 10. sorában ugyanúgy üresen hagyott hely jelzi a lacunát, mint a Parisinus

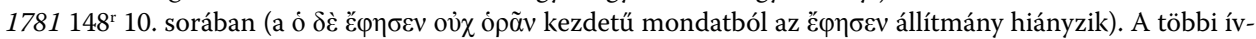
ben a másolók a lacunákat csak elvétve jelzik kihagyással, a szöveg legtöbbször látszólag folyamatos. 
lege szempontunkból azzal a felbecsülhetetlen hozadékkal jár, hogy az eredeti példány pontosan azonosíthatóvá válik, hiszen a reprodukálása tökéletesen megvalósul, s éppen ez az, amiben a másik két ívcsoporthoz képest döntő különbség mutatkozik.

A Reginensis 103 egyetlen biztosan azonosított scriptora, a korfui születésü Antónios Eparchos a szülőföldje ellen intézett török támadás miatt 1537 augusztusában települt át családjával együtt Velencébe. ${ }^{30}$ Az Itáliában görögtanárként és kódexmásolóként is működő Eparchos fő bevételi forrását a görög kéziratokkal folytatott kereskedés jelentette. Elismert szaktudásának, kifinomult ízlésének, kiváló kapcsolatainak, nem utolsósorban pedig páratlan üzleti érzékének köszönhetően a „görög úriember”, ahogyan egyik állandó vevője, Franciaország velencei nagykövete, Guillaume Pellicier (1490-1568) emlegette, rövid idő alatt megkerülhetetlen szereplője lett a görög kódexek másolásával és értékesítésével foglalkozó köröknek, s ezzel akarva-akaratlan nagyban hozzájárult a görög irodalom nyugati elterjesztéséhez. Tevékenységének jelentőségéről tanúskodnak beszerzőkörútjai, ${ }^{31}$ a francia királlyal, Augsburg városával, az Escoriallal vagy éppen a vatikáni könyvtárral kötött nagyszabású üzletei, melyeket az értékesített tételeket tartalmazó részletes eladási katalógusok is alátámasztanak. ${ }^{32}$ Eparchos másolóként is termékeny volt: több mint kétszáz kódex őrzi a kézírását. ${ }^{33}$

Nem mellékes körülmény, hogy a Parisinus 1781 teljes egésze, valamint a Monacensis $307 a$ több ívfüzetének összesen 69 foliuma történetesen Eparchos egyik rokonának, Geórgios Moschosnak a munkája, s ahogy a kéziratok oldaltöréseinek egybeesése bizonyítja, a müncheni kódex szövegét bizonyára a korábban keletkezett párizsi kéziratból másolták. ${ }^{34}$ Antónios Eparchos anyai nagybátyja, a korfui rétorika- és orvosprofesszor, Geórgios Moschos szintén termékeny másolónak számít, írásképét közel háromszáz kéziratban azonosították. ${ }^{35}$ A Reginensis 103 L- és M-íve tanúskodik ugyan kettejük valamiféle munkakapcsolatáról, de ennek részletei nem ismertek. Mindenesetre figyelembe kell vennünk, hogy az L- és M-ívfüzetek Eparchos fiatalkori kézírásának

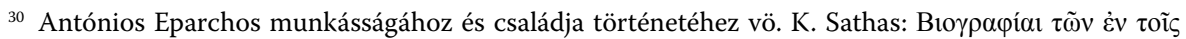

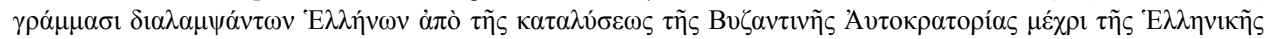

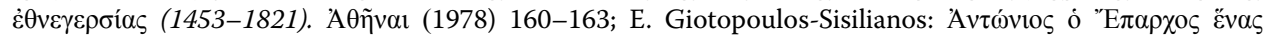

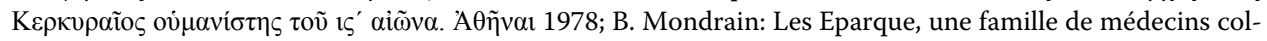
lectionneurs de manuscrits aux XVe-XVI ${ }^{\mathrm{e}}$ siècles. In: The Greek Script in the $15^{\text {th }}$ and $16^{\text {th }}$ Centuries (International Symposium of the National Hellenic Research Foundation, Athens, 18-20 October 1996). Athens (2000) 145-163; B. Mondrain: Jean Argyropoulos professeur à Constantinople et ses auditeurs médecins, d'Andronic Éparque à Démétrios Angelos. In: Polypleuros Nous. Miscellanea für Peter Schreiner zu seinem 60. Geburtstag. Hrsgg. C. Scholz - G. Makris. München - Leipzig (2000) 223-250.

31 Lásd például L. Dorez: Antoine Eparque. Recherches sur le commerce des manuscrits grecs en Italie au XVI siècle. Mélanges d'archéologie et d'histoire 13 (1893) 281-364.

32 Részletesen lásd Giotopoulos-Sisilianos: i. m. (30. j.) 93-131, az eladási jegyzékekhez 287-305.

33 A kézíráshoz lásd RGK I 23, RGK II 32, RGK III 36.

${ }^{34}$ A müncheni kéziratot részletesen leírja: H. Wurm: Der Codex Monacensis Gr. 307a. Ein Beitrag zur Überlieferungsgeschichte des Laonikos Chalkokondyles. JÖB 44 (1994) 455-469. Wurm a következő foliumokon azonosítja Geórgios Moschos kezét: 33-40, 97-120, 134-165, 206-209, 213, 219v-230v 13. sorig.

35 RGK I 67, RGK II 88, RGK III 111. 
jellegzetességeit mutatják, ${ }^{36}$ vagyis elképzelhető, hogy a munka még Itáliába költözése előtt befejeződött.

Áttérve Wurm kijelentésének másik részére, miszerint a Reginensis 103, pontosabban a második és harmadik ívcsoport másolói a Monacensis $307 a$ szövegét vették alapul, egyértelmű bizonyíték híján magunk nem látjuk tisztázottnak a helyzetet. Másképpen fogalmazva: mi bizonyítja, hogy a minta a Monacensis $307 a$ volt, nem pedig a Parisinus 1781? A Reginensis 103 mintájául szolgáló példány azonosítása már csak amiatt is komoly nehézségekbe ütközik, mert a másolók - ellentétben a végletekig pontosságra törekvő Eparchosszal - felületes munkát végeztek (a szöveg hemzseg a kisebb-nagyobb tévesztésektől, olykor többsornyi szöveg hiányzik), a hibák forrását azonban hiába keressük a másik két kézirat valamelyikében. Következtethetünk-e a mintát illetően bármire is abból, hogy például a Reginensis 103 szövege az I-ív korábban más okból már említett első mondatában (

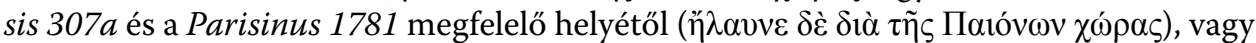

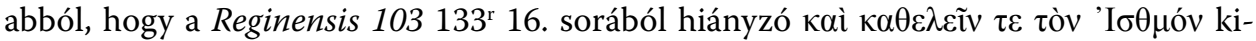
fejezés a másik két kódexben megvan $\left(117^{\vee} 3\right)$ ? Aligha. Az ehhez hasonló példákat akár napestig sorolhatnánk. Nagyobb baj, hogy hiányoznak a rokonságot igazoló látványos párhuzamok is: a Reginensis 103 és a másik két kézirat foliumainak/íveinek kezdősorai nem esnek egybe, ${ }^{37}$ a Reginensis 103 szóban forgó ívfüzeteiben nem találunk marginálisokat, és így tovább.

Bár a Reginensis 103 írásképének vizsgálata a rendelkezésünkre álló fényképfelvételek alapján nem végezhető el a kívánatos pontossággal, annyit megjegyezhetünk, hogy a második ívcsoporthoz tartozó foliumokon talán két, esetleg három másoló keze is elkülöníthető, ${ }^{38}$ de még az sem teljesen kizárt, hogy valamennyi kérdéses ív egyetlen másoló, a harmadik ívcsoportot készítő scriptor munkája, akit feltehetően Eparchos és Moschos köreiben kell keresnünk. A paleográfiai elemzés alapvető nehézségét az jelenti, hogy az íráskép rendkívül ingadozó: a sorok száma ${ }^{39}$ mellett a betűk vastagsága, a sorközök és betűközök nagysága is sűrűn, s ami még inkább zavaró, időnként egy foliumon belül is többször változik, mintha az írnok gyakorlásképpen többféle stílust is szándékosan váltogatna. Közben viszont a betüformák (bár egyes betűk és betűkapcsolatok több változatban is előfordulnak), a rövidítések, az ióta feletti tremák és az ékezetek rendszeres használata a különbözőségek ellenére is azonosságról árulkodnak. Az íráskép fenti ingadozásaira - legalábbis részben - magyarázatul szolgálna az a másolási gyakorlat, ami a Chalkokondylés-szöveghagyományban sem példátlan (sőt a Monacensis $307 a$

\footnotetext{
36 Vö. 15. j.

37 Egyedül a Q-ív első foliuma, a $147^{\mathrm{r}}$ kezdődik pontosan ugyanott, mint a Monacensis 307 a megfelelő helye $69^{\mathrm{r}}$, de a sorok már ezen az egy foliumon belül is elcsúsznak.

38 Darkó: $i$. $m$. (11. j.) 652 a Chalkokondylés szövegben „két, esetleg három kéz” művét véli felfedezni, míg Wurm: i. m. (15. j.) 231 közelebbről meg nem határozott számú, de több másolóról beszél.

39 Az egy foliumon olvasható sorok száma az I-, K-, N- és O-ívek esetében 25-28 között váltakozik.
} 
esetében is éppen ennek a jelenségnek lehetünk tanúi), ${ }^{40}$ nevezetesen amikor többen párhuzamosan másolják ugyanannak a kéziratnak különböző íveit. Ezt a másolási technikát a könyvkészítő mühelyekben gyakran alkalmazták. Andreas Darmariosról például tudjuk, hogy egy-egy kézirat másolását olykor több segédjével párhuzamosan végeztette, mégpedig úgy, hogy ki-ki külön ívekre másolta a neki kijelölt részeket. A Reginensis 103 esetében ez megmagyarázná, hogy miért ingadozik az egyes foliumok sorainak a száma, a másolónak ugyanis egy számára pontosan kijelölt terjedelmet kellett reprodukálnia egy-egy íven, más szóval kénytelen volt folyamatosan figyelni, mennyi hely áll még a rendelkezésére, illetve mennyire kell takarékoskodnia. Maga Darmarios ilyenkor csak az ívek első és utolsó néhány sorát másolta, ő írta a címet, esetleg gondoskodott a díszítésről, majd a másolás végeztével ellenőrizte és szükség esetén javította a szöveget, stb. ${ }^{41}$ Mindez lehetővé tette, hogy a mühely egy-egy kézirat másolásával gyorsabban végezhessen, vagyis gazdaságosabban működhessen. Bár nem kizárt, hogy a Vaticanus Reginensis 103 I-, K-, N- és O-quaternióinak esetében is hasonló áll a háttérben, mindez újabb megválaszolhatatlan kérdéseket vet fel, úgyhogy találgatás helyett tanácsosabb, ha függőben hagyjuk a kérdést.

Annál is inkább, mert a szempontunkból legfontosabb kérdés, vagyis az Apodeixis szövegének kritikai előkészítése tekintetében a hosszúra nyúlt kalandozásunk eredménye mindenképpen ugyanaz lesz: a Vaticanus Reginensis Graecus 103 szövege semmilyen jelentőséggel nem bír a Chalkokondylés-textus megállapításában.

\author{
MÉSZÁros TAMÁs \\ ELTE Eötvös Collegium \\ Byzantium Központ \\ tamas.m.meszaros@gmail.com
}

A cikk a Creative Commons Attribution 4.0 International License (https://creativecommons.org/ licenses/by/4.0) feltételei szerint publikált Open Access közlemény, melynek szellemében a cikk bármilyen médiumban szabadon felhasználható, megosztható és újraközölhető, feltéve, hogy az eredeti szerző és a közlés helye, illetve a CC License linkje és az esetlegesen végrehajtott módosítások feltüntetésre kerülnek. (SID_1)

${ }^{40}$ Még egy Chalkokondylés-kéziratban, a Tubingensis $M b 11$ (U) jelzetűben is hasonlóan magas a kezek (14) és kézváltások (28) száma.

${ }^{41}$ Részletesen lásd O. Kresten: Der Schreiber Andreas Darmarios. Eine kodikologisch-paläographische Studie. Wien (1967) 82-85. 